\title{
Elite Multilingualism. Discourses, practices, and debates
}

\author{
Elisabeth Barakos, Aston University, UK \\ Charlotte Selleck, University of the West of England, UK
}

\begin{abstract}
Yasser is taking an advanced English course, but not for the kinds of teaching, administrative or manual work that dominates research into language learning. Yasser is an international lawyer; for him, language is a key conduit to elite professional circles.
\end{abstract}

Aisha is taking an introductory French class as part of the francization programme in Montreal. She is a medical consultant who has recently moved to Canada to escape the troubles of her homeland and provide a better life for her family. She already speaks three languages but needs to acquire French to improve her chances of finding permanent and well paid work.

These vignettes capture the phenomenon of what we are terming 'elite multilingualism'. In the introduction to the special issue "Elite Multilingualism. Discourses, practices, and debate", we focus on 'elite multilingualism' as a means to provide a window into the complex layers and nuances of today's multilingual, mobile and global society. Our aims here are to provide an empirical and conceptual discussion of a growing language-centred elitism. We also aim to expand current scholarship on the construction, valuation and instrumentalisation of multilingualism, and its consequences for the formation of social boundaries and inequalities. We first discuss major concepts such as the notion of elite/ness and multilingualism, commodification, authenticity and hierarchies and the linguistic market 
in a global knowledge economy. We also discuss the critical sociolinguistic, discourse and ethnographic approaches that frame this special issue and go on to outline the diverse manifestations of elite multilingualism in different educational and social settings. Finally, we conclude by reflecting on the value of the concept of elite multilingualism as a social practice, and argue for the importance of examining the lived experience of multilinguals on the ground.

Keywords: elite multilingualism, eliteness, critical sociolinguistics, ethnography, discourse, commodification, hierarchies

\section{Eliteness and multilingualism: initiating a debate}

New forms of globalization, migration and mobility have led to a re-evaluation of multilingualism as something that has a tangible market value (Angouri 2014; Blommaert and Rampton 2011; Coupland 2010; Duchêne and Heller 2012; Martin-Jones, Blackledge, and Creese 2012). Neoliberalism has redefined the role of the state, society and the economy with an emphasis on growth, freedom, flexibility and individualisation. The social transformations of our time have also re-positioned the role of language learning and teaching driven by the logics of the market. In fact, they have created a conundrum for the role of languages in society: a strengthened role of English as an international and global medium of education and vehicle of access to business and social life; versus a concern for maintaining linguistic diversity. Our current globalising, pluralising and dispersing society is marked by discourses about multilingualism and diversity, which emanate from supranational organisations such as the EU, and other national and local institutional bodies that promote 
the cognitive, social and intercultural benefits of multilingualism (see e.g. Sokolovska's (2016) work on the promotional discourse of the Council of Europe).

As a way of disinventing traditional sociolinguistic concerns with norms, standardization and languages as bounded and homogenous entities, critical applied and sociolinguistic research has concentrated on combating the monolingual bias, and related ideologies including native speakerness, standardness, and the overarching hegemony of global English (e.g. Tupas 2015; Sonntag 2003). Recently, scholarly criticism of the monolingual bias has been influenced by a variety of 'turns' in language education and applied linguistics, e.g. the socio-cultural, reflexive, and multi / pluri turns. These turns acknowledge the growing complexities of multilingualism research and show a re-evaluation of common-sense assumptions in the research field (for critical discussions of these turns, see e.g. Kubota 2016; May 2014; McLaughlin 2016; Ortega 2014; Selleck and Barakos 2018; Weber and Horner 2012). In addition, a growing body of literature has addressed the phenomenon of 'superdiversity' (see e.g. Blommaert and Rampton 2011; Creese and Blackledge 2018 for an overview) to account for the growing complexities, mobilities and repertoires in our current age. This body of research also accentuates the increasing gap between privilege and precarity among migrant communities (see e.g. Flores and Lewis 2016 for a critique of the concept of superdiversity).

In the context of discussions and debates on language maintenance and revitalisation, language minorities and the often underprivileged speaker of certain language(s) (and/or varieties) have been placed in opposition to the dominant, monolingual or multilingual speaker of more dominant and prestigious languages. Critical sociolinguistics have 
questioned such discourses of endangerment that seem to neglect the socio-economic, political and ideological factors involved in the management of diversity (Duchêne and Heller 2007).

From a critical, discursive, sociolinguistic perspective, researchers have identified the shifting motivations for learning and teaching specific languages, and the preferences of one language (or variety) over another, to achieve various differently motivated ends. These include upward social mobility, employment opportunities, entrepreneurship, and access to the global labour market, and extend to more symbolic agendas of identity, language, nation and ethnicity (e.g. Blackledge and Creese 2010; Duchêne and Heller 2012; De Costa, Park, and Wee 2016; Heller 2007; Martín Rojo 2010). As Kubota (2011) further notes, the quest for multilingualism and language learning is now shaped less and less by cosmopolitan or romanticised ideals, but increasingly by instrumental, material and economic purposes, shaped by the rapid spread of neoliberal logics, and exacerbated by wealth inequalities (see also Kubota 2015).

Whilst there is extensive scholarship on elites, education and inequality from a sociologically informed perspective (see e.g. Maxwell 2015; van Zanten 2018, Waters 2018), there has only been scarce scholarship on multilingualism as an ideology of and for the elite (see De Mejía 2002; Jaworska and Themistocleous 2018). The current focus on 'celebratory' discourses on diversity and the use of the term 'diversity' in rather mundane ways appears to deceive and demystify existing elite agendas in a capitalist society (see e.g. research by Del Percio and Sokolovska, 2016; Piller, 2016). As Moore (2017: 238) puts it, this has nurtured an "elite kind of multilingualism". From a European and anglo-centric perspective, this kind of 
multilingualism is valued as an asset, considered useful for business, and linked with entrepreneurship, flexibility and innovation, whilst, he argues, "this same perspective associates non-elite forms of multilingualism with unemployment, urban crime and terrorism (Moore 2015)". Thus understanding the role of multilingualism in elite circles is equally important in the exposition of broader structural inequalities.

In light of these understandings, the papers in this special issue explore the concept of 'elite multilingualism': a phenomenon that brings social and/or material capital, a sense of belonging, prestige, excellence, privilege, and access through the use of specific linguistic resources for certain social groups and individuals. Elite multilingualism is essentially a phenomenon where language serves as an access code to a local, national or global perceived elite (way of life). Whilst we will discuss this concept from various angles in section 2 of this introduction, we would like to emphasise that our aims are here to engage with the multiple and sometimes contradictory ways in which multilingualism becomes a commodifiable object of privilege and prestige, whilst opening a gulf for vulnerability and inequalities in access to eliteness under particular socio-economic conditions and points in time.

In as much as ideologies about monolingualism have been challenged, we argue that it is timely and necessary to interrogate ideologies about bi- and multilingualism that intertwine with issues of social class, ethno-national concerns, and racial and gender divides (e.g. Block 2014; Preece 2009; Preece, this issue). By introducing eliteness as an analytical category, we wish to expand current scholarship on the construction, valuation and instrumentalisation of multilingualism, and its consequences for the formation of social boundaries and hierarchies between "us" and "them (see e.g. Gal and Woolard 2001). We argue that a specific focus on 
eliteness may illuminate further the existing complexity of the dynamic field of multilingualism and the growing literature on social class and language. As Block (2014: 93) argues, education and institutional spaces such as schools or universities in particular are major sites for reproducing social class. Rampton (2010), drawing on Bernstein's accounts of class and language, teases out further specific sites where class reproduction and stratification happens: "the economy, the community, occupations, families, activity, discourse, language, consciousness and school careers" (Rampton, 2010: 5, cited in Block 2014).

On the question of multilingualism, Edwards (1995) aptly stipulates: "To be bilingual and multilingual is not the aberration supposed by many (particularly, perhaps, by people in Europe and North America who speak a 'big' language); it is, rather a normal und unremarkable necessity for the majority in the world today" (Edwards 1995: 1). That said, Edwards (2012) reminds us that 'there is a great deal more to say when we realise that languages are totems as well as tools' (2012: xi). We thus focus on eliteness and multilingualism as an important window (or lens) into today's multilingual, transnational, and diverse society that is driven by a variety of investments to gain access and distinction (Bourdieu 1991). With multilingualism being a ubiquitous phenomenon (Edwards 1995; Busch 2013), we are interested in the politics of investment in and instrumentalisation of multilingualism, and the attendant issues of prestige, privilege, power and gate-keeping. As this collection of studies will demonstrate, such linguistic investments are anchored in current neoliberal market logics and often motivated by economic returns such as access to employment and societal status (Duchêne 2016). 
With all the above in mind, we aim to de-naturalise mundane understandings of 'elite' multilingualism, both from a theoretical and empirical standpoint, by attending to the following key questions:

- Who are 'elite' multilinguals? And what counts as ‘elite multilingualism'?

- How is elite multilingualism as a kind of power regime taken up in different spaces? Which types of elite multilingualism count?

- Are certain languages favoured by 'elite' learners? How are other, less frequently learnt languages and their speakers positioned?

- Who benefits from elite multilingualism and who is marginalised by it and in what ways? To what extent and with what magnitude does elite multilingualism bring about inequalities, hierarchies and stratification?

We believe that such questions should help understand the mobilisation of multilingualism and language learning as sources of investment to increase social power (Darvin and Norton 2016; see also Paquet and Levasseur, this issue), and a means of instrumentalisation for specific social actors and groups. Through adopting a problem-oriented approach, such questions also allow us to think through "what is taken for granted, indicating problematic discursive [and social] practices by policymakers and other elites, and challenging dominant ideologies and normative assumptions" (Barakos and Unger 2016: 3) about the role of language and the way people use language in social life.

Through the course of this special issue, we will show that elites/elitism vary and are rather nuanced. They range from different locations and institutions of power (private schools and 
universities) to different actors (parents, native teachers, head teachers, school coordinators, students), as demonstrated in the various contributions by Codó and Sunyol, Preece, and Relaño-Pastor and Fernández-Barrera). Elite multilingualism is also experienced, perpetuated and aspired to by newcomers to countries (Paquet and Levasseur) and other 'ordinary' people with capacities and aspirations to acquire and retain symbolic and / or material capital to realize an elite trajectory (Hornsby). In section 2, we give a fuller account of elites and characteristics of eliteness.

Methodologically, the various papers in this special issue address elite multilingualism through ethnographic and qualitative, discourse-analytic approaches as well as perspectives from the 'political economy of language' approach (see Del Percio, Fluchbacher and Duchêne 2016 for an overview; see also Ricento 2015; Gal 1989) and in doing so reflect both an emic and etic perspective. Such approaches hold that language use is anchored in specific socio-political, cultural and historical contexts that need to be considered when making sense of specific situated discursive and social practices. The objective of a critical, sociolinguistic engagement with language lies in "describing, understanding and explaining the role of language in constructing the relations of social difference and social inequality that shape our world" (Heller 2011, 34; see also Heller, Pietikäinen and Pujolar 2018; Pérez-Milans 2013). An ethnographic approach aims to "describe the apparently messy and complex activities that make up social action" (Blommaert and Dong 2010: 12), whilst a political economy approach to language and multilingualism helps to re-address key questions of interest to the study of language in society more broadly: inequalities, privilege, social stratification and power. 
In the remaining parts of our introduction, we first discuss the defining features of elite multilingualism in contemporary sociolinguistics and elucidate the terms 'elite'/ 'eliteness', 'multilingualism', and 'elite multilingualism' (section 2). We then consider salient concepts that characterize the conditions and materialisations of elite multilingualism such as the 'commodification of language', 'language ideologies', 'hierarchies' and 'authenticity' (sections 3 and 4). We finally introduce the contributing papers to this special issue (section 5), and conclude by re-addressing the importance of engaging with elite multilingualism as a new way of approaching multilingualism through a critical, sociolinguistic lens (section 6).

\section{What is elite/eliteness and elite multilingualism?}

We argue it is important to interrogate what the notions of 'language' and 'multilingualism' entail first to allow a meaningful conversation of the concept of "elite multilingualism". Whilst there are abundant approaches to these salient concepts, we conceive of language here in a Bourdieuian sense as capital and power (Bourdieu 1991), that is, 'a practice as well as a resource that can have both symbolic value and exchange value in a market economy' (Duchêne et al., 2013: 5; see also Codó and Sunyol, this issue; Martin-Jones, Blackledge, and Creese 2012), see below for further discussion. Multilingualism is then a fluid and flexible set of communicative practices, a continuum that is context-dependent and socially marked. In this vein, "multilingualism is not only inequitable but also gradient" (Ortega 2018: 3). There is always a degree of valuation and hierarchisation attached to different forms of linguistic practices in society. As such, not all 'multilingualisms' are equal, and multilingualism per se is not neutral but rather hierarchical and ideologically invested (see below for further discussion of hierarchisation). It is a fuzzy, messy and ubiquitous phenomenon that comes in different shapes and grades (Ortega 2018). 
Similar to multilingualism, elites and eliteness are not necessarily new phenomena if we think of them in terms of social inequality and social class - something that has always existed but has now, in our times of internationalisation, mobility and migration, regained currency when people talk about, institutions plan for and speakers live multilingualism. Who then are the 'elites'? There is no singular definition of what an elite is and in this sense it is useful to conceive of it as something that is not monolithic or static. Sonntag (2003) argues that "different elites draw on different capitals to acquire and retain their elite status" (Sonntag 2003: 8) and that there are different "clusters of elites" and different sorts of "elite capital" that overlap: political, economic, cultural, and linguistic ones. In the context of elite humanitarian transnational professionals, Garrido (2017) uses the concept of 'cosmopolitan capital', inspired by Igarashi and Saito (2014), to denote a form of cultural capital that entails openness and solidarity as well as communication skills and competences to realize and maintain elite status. Beaverstock's (2005) research on inter-company transferees casts 'elites' as the 'agents and beneficiaries' (p. 250) of economic globalisation since they are able to 'capitalise on their knowledge, skills and intelligence' (p. 250) across borders. Relatedly, Barakos (2018) discusses the 'neo-liberal worker', someone she defines as being 'adaptable, subject to certification and who embodies entrepreneurial values' (Barakos 2018: 3).

In a Bourdieuian sense, we argue that a) eliteness is linked to beliefs (ideologies), aspirations, power and influence; b) elites inherently involve classifications and hierarchization; c) elites are formed through social contact, i.e. they are a (self)defined and perceived social group of individuals who share a common range of characteristics based on 
perceived superiority and patterns of inclusion and exclusion (see section 3 for further discussion).

Along these lines, we also conceptualise elites/eliteness as a socially relevant and dynamic category, a lens through which to view certain linguistic contexts in order to talk about the mobilisation and access to different forms of symbolic and material capital. Thus, eliteness is also a discursive construct imagined, characterised, (re)shaped and reproduced in popular narratives and by the acts of people. We therefore align with scholars who emphasise the agentive and discursive nature of elites/elitism (Maxwell and Aggleton 2013; Thurlow and Jaworski 2017). In this sense, eliteness is "something people do, not something they necessarily have or are" (Thurlow and Jaworski 2017: 244). Accordingly, we treat eliteness as a continuum that is shaped in and through individual and collective discourses and practices. A continuum approach helps us avoid oversimplifying eliteness and non-eliteness as 'the rich' and 'the poor' as the two very distinctive ends. A continuum from non-elitist to very elitist as anchor points help us explain the different characteristics of eliteness that we can find along the continuum. These characteristics are not reducible to monetary wealth and possession but include levels of education (e.g. see Codó and Sunyol for the context of a Barcelona international school) and more nuanced, subtle and embedded configurations that may not appear to be elite in terms of tangible wealth (e.g. Hornsby's contribution on new speakers as privileged in that they can learn a 'new' language although it doesn't seem to conform to more traditional or lay conceptions of eliteness). Eliteness can, as will be seen, be more symbolic or real; it is something relative to one's lived experience, life history and trajectory (for a full discussion see sections 3 and 4 below). 
Elite multilingualism, then, is a phenomenon that imbues social and/or material capital, prestige, excellence, privilege, and access to linguistic resources in certain groups of speakers. Elite multilingualism describes the use of language as an access code to a local, national or global perceived elite (way of life). Elite multilingualism is also emotion-laden and interlocked with affective dimensions of language learning and use (see De Costa, this issue). As we can trace across most contributions, this affective work plays out in frustrations, anger and pain to satisfaction, desires, and pride. These emotions mediate the elite multilingual experience and nurture different perceived positions of authority and hierarchy and processes of resistance. And lastly, elite multilingualism has an aspirational dimension. It is not only a status quo (as discussed in Preece, this issue). It is often a promise or constructed as such with the aim to make people aspire to it. Yet, elite multilingualism is not something everyone can equally attain and is thus a terrain for exclusion (see Paquet and Levasseur; Codó and Sunyol, this issue).

Eliteness here serves as a new way of looking at and approaching multilingualism. In such an endeavour, we start from the premise that it is essential to de-centre language by paying attention to the social, affective, cultural, political, and economic processes that shape the way language is used to carve out something 'elite'. So for us, it is relevant to put the focus away from language as the mere point of inquiry and also look at which agents, bodies, institutions and affective stances are involved in (re)producing eliteness and what kinds of knowledge specific elites produce (see also De Costa, this issue, for an account of elite multilingualism). 
What we are describing here, the use of language as a means to accessing elite circles, has not received much attention in the field of multilingualism and bilingual education research. Nevertheless, a range of scholars provide us with useful jumping off points. Jaworska and Themistocleous (2018: 21) talk about an "elite bilingualism/multilingualism" in the context of the UK: a multilingualism that precisely values the learning and teaching of prestigious languages such as French, English and Spanish as markers and gatekeepers to a privileged way of life and is linked to formal school and university education, a range of qualifications and prestigious employment opportunities, and seems to devalue if not exclude immigrant languages. Similarly, Lanvers (2017) establishes a growing eliteness and social divide in language learning in the UK (see also Pachler 2007). Rydenvald (2015) also employs the term 'elite bilinguals', inspired by Paulston (1978), to study multilingualism based on free choice. In particular, she looked at the language use and language attitudes of multilingual Swedish teenagers who attend European and international schools - a somewhat more constrained context than ours, but still an important foundation (Rydenvald's work would certainly fit as an example of what we are describing).

Elsewhere, in the context of Latin America, De Mejía (2002) and Guerrero (2010) discuss an array of terms that are circulating, such as 'additive bilingualism', 'voluntary bilingualism', or 'privileged bilingualism' and give an account of middle class children who attend international education programmes to learn high prestige languages in globalising circumstances. De Mejía (2002: 5) captures elite bilingualism here as a world-wide phenomenon; a type of bilingualism that is "highly visible, provides access to prestigious international languages for those upwardly mobile individuals and their families who need or who wish to be bilingual or multilingual". In the Canadian French-English minority context, 
Heller (2002: 49) uses the term 'elite bilingualism' to capture the pervasiveness of "standard and monolingual forms and practices largely acquired through literacy", as opposed to a 'working-class bilingualism' that consists of mixed language forms and mostly orally acquired practices. Day and Wagner (2007) add the term 'bilingual professional' to the scholarly debate of voluntary migration for social advancement. With this term, they seek to capture "the bilingualism of individuals who have the means to voluntarily learn a new language with which they might improve their work-life chances" (Day and Wagner 2007: 381).

What these definitions have in common is a focus on eliteness as someone or something being perceived as having more value than something or someone else (a higher value and therefore more worth). There are a range of moral evaluations attached to elite multilingualism as something better or a promise of becoming a better person, which creates the imperative to strive for it. And yet, such morales leave us with a conundrum: those who already have some material and cultural resources are able to 'do eliteness' and 'become elite', whereas those who do not are left out.

The groundwork for understanding elite multilingualism is laid in commodification processes of the new economy: how the commodity value of specific communicative resources is discursively constructed and identified by both individuals and institutional social actors. We turn to this in the next section. 


\section{Commodification of language, commercialisation and marketisation}

As noted above, Heller (2010) posits that the globalized new economy is bound up with myriad transformations of language and identity (see also e.g. Bauman 1997; Castells 2000; Giddens 1990). In recent years the term 'commodification' has entered the sociolinguistic lexicon, used varyingly to refer to language being treated as 'an objective skill, acquired and possessed, that affords status, recognition legitimacy, and ultimately material remuneration, to those who possess it' (Block 2017: 6). This is not in itself new; Bourdieu's classical conceptualisation of linguistic capital $(1982,1991)$ posits language as a set of attributes that a person can accumulate in order to establish or improve their social position (Eckert 1989). Hogan-Brun (2017) talks of 'linguanomics' to assert that languages can have a 'market-value' (2017:xii) and that language competency can be discussed in terms of 'assets' (2017:xii). These 'attributes' or 'assets' are available to be exchanged in the 'marketplace' of social interaction.

In a sense, language itself has no tangible value. Rather, as Gal (1989) argues, 'because linguistic practices provide access to material resources, they become resources in their own right' (p353). In other words, the 'value' of a linguistic variety depends on its standing in a linguistic marketplace and its ability to give access to desired positions in the labour market. Gal (1989) further posits that certain varieties of language are given more legitimacy through the recognition they receive by formal institutions such as schools (see below for discussion of hierarchisation). Consequently, we suggest that elite language learners are subjected to and treated as consumers, are able to 'choose' certain codes over others. Selleck (under review) has argued that the ideology of choice is 'a reflection of the market-driven demand for certain types of education and is inextricably linked, ideologically at least, to consumerism'. 
We argue that the 'idea' of choice is fundamentally entrenched with a neoliberal rationality that propagates the idea that we are all free to choose our course in life. Choice is also linked to an idea of human capital, which seeks to recognise the 'knowledge, skills, competencies and attributes embodied in individuals that facilitate the creation of personal, social and economic well-being' (OECD 2001). Paquet and Levasseur (this issue) and Codó and Sunyol (this issue) portray people quite literally 'buying into' languages by 'choosing' to acquire one or more 'prestigious' languages and/or language varieties and in this sense align with McGroarty (2006) who suggests that 'effective and socially just language policies must recognise the moral, as well as material aspects of education' (p3). Meanwhile De Costa (this issue) interprets such choices slightly differently, as a form of constraint, a rational reaction to 'new forms of control' (Devadason 2017: 2266) and aligns with Petrovic (2005) in arguing that the 'language as resource' (Ruiz 1984) strategy to language planning, one that involves an association of language with social and economic status, often results in a preservation of the status quo in terms of social inequality and language choice (see Preece, this issue, for an in-depth engagement with the 'language as resource' approach).

Additionally, the commodification of language relies on and is shaped by people's 'beliefs about language' and their 'rationalization or justification of perceived language structure and use' (Silverstein 1979: 193), in short, their language ideologies. Irvine (1989) argued that ways of speaking are not always 'merely an index of some independently generated social differentiation' (p255) but may indeed effect social differentiation. Language ideologies, therefore, play a 'crucial mediating factor' (ibid.) in the link between language and the economy, insofar as beliefs people have about language are inseparable from other elements 
of their lives and their social experiences (see Relaño-Pastor and Fernández-Barrera, this issue, for language ideological accounts of eliteness and the native self).

Blackledge argues that 'ideologies of language are therefore not about language alone, but are always socially situated and tied to questions of identity and power in societies' (Blackledge 2000: 27). Suggesting that ideologies are linked to power implies dimensions of inequality, something that Heller more explicitly picks up on in her definition of ideology. Heller posits that language ideologies are 'discourses in which processes of attribution of value to linguistic forms and practices are inscribed, along with the processes of construction of social difference and social inequality within which they are associated' (Heller 2007: 15). The socially positioned and contestable nature of language ideologies means that they contribute to inequality and social hierarchisation, and they are thus about asserting the relationship between language and power and social structure. The notion of inequality and social difference is salient to the research presented here, in that it is focused on how the notion of eliteness can be used as a lens through which to view certain linguistic contexts as well as the lived experiences of people active within these contexts, how people frame their understanding of linguistic varieties and the difference amongst them. In this way then, the articles in this special issue take up the call to advance this line of inquiry 'through their shared focus on what happens to languages and their speakers as they move into the realm of commodification' (Cavanaugh 2018: 261).

Whilst the commodification process has, in many ways, served to reinforce the market positioning of 'big' languages such as English (Piller and Cho 2013; Sayers and Lea Láncos 2017; Preece, this issue; Relaño-Pastor and Fernández-Barrera, this issue; Codó and Sunyol, 
this issue), there are also "new possibilities for investing in "small" languages and language varieties, including minority languages" (Brennan 2018:160) - a number of which are discussed in this special issue (Hornsby, this issue; Paquet and Levasseur, this issue). Recent flourishing scholarship on new speakers has grappled with the motivations of 'new' speakers, establishing that motivations can vary (Ó Murchadha et al. 2017), with some speakers citing 'instrumentality' (p.5) as a motivating factor (e.g. gaining employment) whilst others identify a 'symbolic motivation' (p.5), recognising the 'integrative and identificational potential of language' (p.5). Aligning with Sharma (2018) we also argue that there is sometimes a desire to become more competent (or to acquire certain competencies) in linguistic codes, to improve fluency levels (see also Barakos 2018 for similar aspirations in adult language training).

\section{Hierarchies}

If we accept that languages are, at least for some people, commodified then it follows that sociolinguistic hierarchies may emerge. In other words, the "transformation of the ontological status of language from an immaterial or abstract realm of reality to a material one' (Shankar and Cavanaugh, 2012: 362) sees the possibility of languages and language users being ordered based on perceptions and beliefs of and about the value of particular languages or varieties of language relative to others. In this sense some language varieties take on or are imbued with more prestige than others - a prestige that seems broadly to relate to the perceived socioeconomic and mobility advantages that a language affords (or is perceived to afford). These affordances are indeed demonstrated by all the contributions to this special issue. 
In a European context, Jaspers (2009: 19), speaks of the 'prestige' or 'pure' multilingual referring to the upwardly mobile, highly educated, higher socioeconomic status learners of two or more internationally useful languages. Jaspers places these in opposition to the 'plebeian' or 'impure' multilingual - referring to the use of various (regional or minority) language varieties by a mostly urban, largely multi-ethnic, very often poorly educated ‘working class' across Europe. Sayers and Láncos (2017) describe a 'multilevel language hierarchy' distinguishing between ‘working languages, official languages and the non-official languages' (2017: 35) of the European Union; and point out that 'allochthonous ('immigrant') languages are discounted, despite outnumbering autochthonous ('indigenous') languages' (Sayers and Láncos 2017: 35). Their analysis focuses on hierarchies engendered by EU law and bureaucracy. This is notable for our purposes, but in line with Muth and Del Percio (2018) we also stress that changing 'market demands result in shifting values of linguistic repertoires' (2018: 33). Thus the hierarchy for elite multilingualism is constantly shifting, faster than institutional/legal frameworks, and is context-dependent (see Hornsby, this issue, on the multiple stratifications and authenticities of Breton speakerhood and Codó and Sunyol on the institutionalisation of Mandarin Chinese in an elite school). This special issue disentangles the paradoxical situation of valuing some types of languages and language users more than others. In other words, we seek to understand why the rewards (symbolic or real) for using some types of languages may be higher than others and additionally why some speakers are more highly prized than others.

We argue that Bourdieu's $(1982 ; 1991)$ notion of symbolic and linguistic capital helps clarify that the positioning of certain language codes is dependent not only on the perceived value attached to them but the nature of the 'linguistic marketplace' (see the discussion of 
commodification above). Costa (2015: 129) suggests that the price of minority languages (or the symbolic rewards for using such languages) is usually very low on 'unified linguistic markets' (those dominated by one official language), but may receive a higher price on niche markets where they can index a sense of community, solidarity or authenticity (Costa 2015:129). This has also been demonstrated by Kelly-Holmes and Pietikäinen's (2014) work on the commodification of Sámi language and culture in tourism and Selleck (under review) in the Welsh educational context. This collection seeks to explore how 'elite' multilingualism plays out in various spaces and with what social and linguistic consequences.

\section{The papers in this special issue}

The articles within this special issue aim to engage with nuanced forms of elite multilingualism. They closely examine the lived reality, trajectory and journey of the elite multilingual, and those who aspire to become so or those who aspire it for their children.

This special issue grew out of a conference colloquium we organized at the Sociolinguistics Symposium 2016 in Murcia, Spain. The papers identify and analyse key moments where power, hierarchisation, marginalisation and inequalities arise as part of processes of elite multilingualism. The contributors underline the importance of moving away from mundane celebratory approaches to multilingualism to more critically oriented questions of what multilingualism actually means for specific social actors.

The five original contributions in this issue are followed by a discussion from Peter De Costa. The studies allow us to think through the relationship between eliteness and multilingualism, what elite multilingualism constitutes, and how it is constructed and lived out in Montreal, 
Barcelona, Castilla la Mancha, Brittany, and London. Throughout, the authors draw out more broadly generalisable themes.

The first paper, by Paquet and Levasseur, takes the concept of 'new speakers' as a lens for discussing formations of elite multilingualism in Montreal, Canada. Through an ethnographic study, they trace the experience of multilingual newcomers who attend the 'francization' programmes as new speakers of French. For these immigrant learners, French and English are invested with symbolic and material value that offers them a path for upward social mobility. Yet, despite the pervasive ideology of a balanced French-English bilingualism that is considered elite, and desirable, their own plurilingual repertoires have currency; this challenges the perceived and discursively constructed elite/non-elite boundaries in Montreal.

The second paper, by Hornsby, discusses eliteness as hierarchies of Breton speakerhood in a minoritized setting. Taking a discursive approach, Hornsby links speaker stances and narratives to discourses of tradition, modernity, and globalisation. He shows the persistent ideal of linguistic authenticity and processes of 'othering' amongst Breton speakers, and the ways different social actors position themselves as 'elite' or the 'counter-elite' (e.g. groups of nativist new Breton speakers opposed to innovation or standardization of the language).

In the third paper, Preece provides an insight into the role of institutional elite and non-elite multilingualism and the stratification of linguistic diversity in the student population of two distinct university settings in the UK. Eliteness here is very much a "classed identity". Preece's ethnographically informed study demonstrates the ways Anglophone higher education institutions reproduce an elite/non-elite linguistic binary in terms of repertoires of 
socially more and less privileged students, with an erasure of immigrant students' community language backgrounds.

The fourth contribution, by Relaño-Pastor and Fernández-Barrera, investigates the pervasiveness of English native speakerism in elite education in Spanish-English CLIL (content and language integrated learning) bilingual programmes in the autonomous community of Castilla-La Mancha (Spain). Through a critical sociolinguistic ethnography and political-economic perspective, the authors trace circulating discourses, ideologies and practices of bilingualism and bilingual education. They take up the link of eliteness and native speakerism amidst the global market of English language teaching and learning, and neoliberal logics that define multilingualism by accreditation and international certification processes.

The fifth paper, by Codó and Sunyol, investigates the institutionalisation of Mandarin Chinese in an elite international school in Barcelona, Spain. The distinct focus on Chinese, next to English, Spanish and Catalan, represents a new source of distinction; and exclusive but also speculative educational capital. Codó and Sunyol link the discussion of eliteness with language commodification, neoliberal subjectivities and the notion of investment through a critical sociolinguistic ethnographic enquiry.

De Costa's discussion piece concludes this special issue by charting the link of elite multilingualism to affect and neoliberalism, and poses central questions over why elite multilingualism occurs, who and what enables elite multilingualism, what the effects of elite multilingualism are, and how we can "rebuff elite multilingualism". This contribution clearly 
teases out the affective dimensions and emotion work going on in terms of elite multilingualism across all papers and the ways these emotions (as part of subjectivities) can lead to moments of resistance and counter stances. De Costa's contribution also shows up the need for being constantly reflexive in terms of the theoretical, methodological and empirical directions of our research.

\section{Conclusions}

In sum, this special issue engages with eliteness as an under-explored phenomenon in contexts of language learning and language use. This represents a new way of approaching multilingualism through a critical, sociolinguistic lens, and provides a window into the complex layers and nuances of today's multilingual, mobile and global society. By exploring the multiple ways in which highly skilled professionals use languages, we are ultimately attempting to add theoretical depth and empirical breadth to the notion of eliteness.

It was argued above that increased inter-connectivity and globalisation has left its mark on language and identity, and on the way we live, learn and work. These transformations can leave an imprint on individuals and groups; and this collection seeks to provide a snapshot of five such cases. We aim to provide a foundation for further substantive debate on elite multilingualism as a social practice - debate that considers the "conditions and consequences of language for people" (Heller, Pietikäinen and Pujolar 2018: 4).

Social exclusion and inequality has long been a focus in sociolinguistics (Lawson and Sayers 2016). The focus, however, has tended to be on disadvantage, on those trapped lower down the social ladder. We advance the debate by shining a light the other way, on eliteness. We do 
this whilst also acknowledging, as Deumert (2018) does, our own relatively privileged roles in academia with regards to knowledge production. We are in the fortunate position to watch, research and engage with topics and contexts of our choice. There is of course a degree of instinctive indignance out there about cloistered academics focusing imperiously on fellow global elites. This is understandable but, we argue, misplaced. We echo Thurlow and Jaworski (2017), who argue that it is only by "paying attention to the other end of the so-called class spectrum' that we can only fully grasp issues of inequality, marginality and disadvantage.

In sum, we propose that this special issue is also a way to argue for concerted reflection and criticality and that it will allow for a decentering of the debates on what counts as elite multilingualism and shift the focus from a theoretical standpoint to focus on the lived experience of elite multilingualism 'on the ground' (Hornberger and Hult 2008: 285).

\section{References}

Angouri, J. (2014). "Multilingualism in the workplace: Language practices in multilingual contexts". Multilingua 33 (1-2): 1-9.

Bauman, Z. (1997). Postmodernity and its Discontents. London: Routledge.

Barakos, E. (2018). Multilingual language trainers as language workers: a discourse-ethnographic investigation. Language and Intercultural Communication.

Barakos, E., and Unger, J. W. (2016). Introduction: why are discursive approaches to language policy necessary? In E. Barakos, and J. W. Unger (Eds.), Discursive approaches to language policy. London: Palgrave, 23-49. 
Beaverstock, J. (2005). “Transnational Elites in the City: British highly skilled inter-company transferees in New York City's financial district”. Journal of Ethnic and Migration Studies 31 (2): 245-68.

Blackledge, A. (2000). "Monolingual ideologies in multilingual states: Language,hegemony and social justice in Western liberal democracies". Estudios de Sociolingüística 1 (2): 25-45.

Blackledge, A., and Creese, A. (2010). Multilingualism. A critical perspective. London: Continuum.

Block, D. (2014). Social class in applied linguistics. London, UK: Routledge.

Block, D. 2017. What on earth is 'language commodification'? In S. Breidbach, L. Küster and B. Schmenk (Eds.), Sloganizations in language education discourse. Bristol: Multilingual Matters.

Blommaert, J., and Dong, J. 2010. Ethnographic Fieldwork: A Beginner's Guide. Bristol: Multilingual Matters.

Blommaert, J. (2011). "The long language-ideological debate in Belgium". Journal of Multicultural Discourses 6 (3): 241-256.

Blommaert, J., and Rampton, B. (2011). “Language and superdiversity”. Diversities 13 (2): 1-22.

Bourdieu, P. (1982). Ce que parler veut dire. Paris: Fayard.

Bourdieu, P. (1986). The forms of capital. In J. Richardson (Ed.), Handbook of theory and research for the sociology of education (pp. 241-258). New York: Greenwood. 
Bourdieu, P. (1991). Language and symbolic power (1st ed.). Cambridge: Polity Press.

Busch, B. (2013). Mehrsprachigkeit. Wien: Facultas/UTB.

Brennan, S. (2018). "Advocating commodification: an ethnographic look at the policing of Irish as a commercial asset". Language Policy 17: 157-177

Castells, M. (2000). The Information Age: Economy, Society and Culture. Oxford: Blackwell.

Coupland, N. (Ed.) (2010). The handbook of language and globalization. Malden: Wiley-Blackwell.

Cavanaugh, J. (2018). “Linguistic Economies". Commentary on Language Policy Special Issue "Policing for Commodification: Turning Communicative Resources into Commodities". Language Policy 17 (2): 261-273.

Costa, J. (2015). "New speakers, New language: On Being a Legitimate Speaker of a Minority Language in Provence". International Journal of the Sociology of Language 231: 127-145.

Creese, A., and Blackledge, A. (Eds.) (2018). The Routledge Handbook of Language and Superdiversity. London: Routledge.

Darvin, R., and Norton, B. (2016). "Investment and language learning in the 21 st century". Langage et Société, 157 (3): 19-38.

Day, D., and Wagner, J. (2007). Bilingual professionals. In Auer, P. and L. Wei (Eds.), Handbook of multilingualism and multilingual communication (pp. 391-404). Berlin, Germany: De Gruyter. 
Deumert, A. (2018). Plenary at Communication in the Multilingual City, TLANG conference, University of Birmingham, 28-29 March 2018.

Devadason, R. (2017). "The golden handcuffs? Choice, compliance and relocation amongst transnational professionals and executives". Journal of Ethnic and Migration Studies 43 (13): 2265-2282, DOI: 10.1080/1369183X.2016.1260444

De Costa, P., Park, J., and Wee, L. (2016). “Language learning as linguistic entrepreneurship: Implications for language education". The Asia-Pacific Education Researcher 25 (5-6): 695-702.

Del Percio, A., and Sokolovska, Z. (2016). "Discourses of diversity". Language and Communication 51: 1-4.

Del Percio, A., Flubacher, M., and Duchêne, A. (2016). Language and political economy. In O. Garcia, N. Flores, and M. Spotti (Eds.), Oxford handbook of language in society (pp. 55-75). New York: Oxford University Press.

De Mejía, A. M. (2002). Power, prestige, and bilingualism: International perspectives on elite bilingual education. UK: Multilingual Matters Ltd.

De Mejía, A. M. (2005). Bilingual education in Colombia: Towards an integrated perspective. In De Mejía, A. M. (Ed.), Bilingual education in South America (pp. 48-64). UK: Multilingual Matters Ltd.

Duchêne, A. (2016). "Investissement langagier et économie politique". Langage et Société 157: 73-96.

Duchêne, A., and Heller, M. (Eds.). (2007). Discourses of endangerment. Ideology and interest in the defence of languages. London: Continuum. 
Duchêne, A., and Heller, M. (Eds.). (2012). Language in late capitalism. Pride and profit (1st ed.). New York: Routledge.

Duchêne, A., Moyer, M. G., and Roberts, C. (Eds.). (2013). Language, migration and social inequalities. A critical sociolinguistic perspective on institutions and work. Bristol: Multilingual Matters.

Eckert, Penelope. (1989). Jocks and burnouts: Social categories and identity in the high school. New York: Teachers College Press.

Edwards, J. (1995). Multilingualism. London: Penguin.

Edwards. J. (2012). Multilingualism: Understanding Linguistic Diversity. London and New York: Continuum.

Flores, N., and Lewis, M. (2016). "From truncated to sociopolitical emergence: A critique of super-diversity in sociolinguistics". International Journal of the Sociology of Language 241: 97-124.

Gal, S. (1989). "Language and political economy". Annual Review of Anthropology 18: $345-367$.

Gal, S., and K. Woolard. (2001). Languages and Publics: The Making of Authority. Manchester: St. Jerome's Press.

Garrido, M. R. (2017). "Multilingualism and cosmopolitanism in the construction of a humanitarian elite”. Social Semiotics 27 (3): 359-369. DOI:10.1080/10350330.2017.1301800

Giddens, A. (1990). The Consequences of Modernity. Berkeley. California. University of California Press. 
Guerrero, C. H. (2010). "Elite Vs. Folk Bilingualism: The Mismatch between Theories and Educational and Social Conditions". HOW, A Colombian Journal for Teachers of English 17 (1): 165-179.

Heller, M. (2002). Éléments d'une sociolinguistique critique. Paris: Didier.

Heller, M. (2002). "Globalization and the commodification of bilingualism in Canada". In: D. Block and D. Cameron (eds.), Language Learning and Teaching in the Age of Globalization. London: Routledge, pp. 47-63.

Heller, M. (2007). Bilingualism as ideology and practice. In M. Heller (Ed.), Bilingualism: a social approach (pp. 1-24). Basingstoke: Palgrave Macmillan.

Heller, M. (2010). "The Commodification of Language”. Annual Review of Anthropology 39: 101-114.

Heller, M., Pietikäinen, S., and Pujolar, J. (2018). Critical Sociolinguistic Research Methods: Studying Language Issues That Matter. London: Routledge.

Hogan-Brun, G. (2017). Linguanomics: What is the Market Potential of Multilingualism. London: Bloomsbury.

Hornberger, N., and Hult, F. M. (2008). Ecological language education policy. In B. Spolsky and F. M. Hult (Eds.), The handbook of educational linguistics (pp. 280-296). Oxford: Blackwell.

Igarashi, H., and H. Saito. 2014. "Cosmopolitanism as Cultural Capital: Exploring the Intersection of Globalization, Education and Stratification". Cultural Sociology 8 (3): $222-239$.

Irvine, J. (1989). "When Talk isn't cheap: language and political economy". American Ethnologist 16 (2): 248-267. 
Jaspers, J. (2009). Inleiding [Introduction]. In J. Jaspers (Ed.), De klank van de stad: Stedelijke meer-taligheid en interculturele communicatie [The sound of the city: Urban multilingualism and inter-cultural communication] (pp. 7-32). Antwerp: Acco.

Jaworska, S. and Themistocleous, C. (2018). "Public discourses on multilingualism in the UK: triangulating a corpus study with a sociolinguistic attitude survey". Language in Society 47 (1): 57- 88. ISSN 00474045 doi: https://doi.org/10.1017/S0047404517000744

Kelly-Holmes, H., and Pietikäinen, S. (2014). "Commodifying Sámi culture in an indigenous tourism site". Journal of Sociolinguistics 18: 518-38.

Kenway, J., and McCarthy, C. (Eds.). (2016). Elite Schools in Globalising Circumstances: New Conceptual Directions and Connections. London: Routledge.

Kubota, R. (2011). "Questioning linguistic instrumentalism: English, neoliberalism, and language tests in Japan". Linguistics and Education 22: 248-260. doi:10.1016/j.linged.2011.02.002

Kubota, R. (2015). "Neoliberal paradoxes of language learning: Xenophobia and international communication". Journal of Multilingual and Multicultural Development 37 (5): 467-480.

Kubota, R. (2016). "The Multi/Plural Turn, Postcolonial Theory, and Neoliberal Multiculturalism: Complicities and Implications for Applied Linguistics". Applied Linguistics 37 (4): 474-94.

Lanvers, U. (2017). Elitism in language learning in the UK. In D. J. Rivers and Zotzman, K. (Eds.), Isms in language education. Berlin: Mouton de Gruyter, Berlin, pp. 50 - 73. 
Lawson, R., and Sayers, D. (2016). Where we're going, we don't need roads: The past, present and future of impact. In R. Lawson, and D. Sayers (eds.), Sociolinguistic research: Application and impact. Abingdon: Routledge. 7-22.

Martin-Jones, M., Blackledge, A., and Creese, A. (Eds.). (2012). The Routledge Handbook of Multilingualism. London, UK and New York, NY: Routledge, 2012.

Martín Rojo, L. (2010). Constructing Inequality in Multilingual Classrooms. New York: Mouton De Gruyter.

Maxwell, C. (2015) 'Elites': some questions for a new research agenda. In van Zanten, A., Ball, S. and Darchy--Koechlin, B. (eds). Elites, privilege and excellence: The national and Global redefinition of educational advantage. London: Routledge.

Maxwell, C., and Aggleton, P. (2013). Privilege, Agency and Affect: understanding the production and effects of action. Houndmills: Palgrave Macmillan.

May, S. (Ed.). (2014). The Multilingual Turn: Implications for SLA, TESOL and Bilingual Education. New York: Routledge.

McGroarty, M. (2006). "Neoliberal Collusion or Strategic Simultaneity? On multiple rationales for language-in-education policies”. Language Policy 5: 3-13.

McLaughlin, M. (2016). "Linguistic Minorities and the Multilingual Turn: Constructing Language Ownership through Affect in Cultural Production". Multilingua 35 (4): 393-414.

Moore, R. (2017). Discourses of Endangerment. In Garcia, O.; Flores, N. and Spotti, M. (eds.), The Oxford Handbook of Language and Society, pp. 221-242. Oxford: OUP.

Muth, S., and Del Percio, A. (2018). "Policing for commodification: turning communicative resources into commodities". Language Policy 17: 129-135. doi:10.1007/s10993-017-9441-7. 
OECD (2001). "The Well Being of Nations: The Role of Human and Social Capital". Organisation for Economic Co-operation and Development 2001.

Ó Murchadha, N.P., Hornsby, M., Smith-Christmas, C., and Moriarty, M. (2017). New Speakers, Familiar Concepts? In Smith-Christmas, C., Ó Murchadha, N.P., Hornsby, M., and Moriarty, M. (eds.), New Speakers of Minority Languages. Linguistic Ideologies and Practices, pp. 1-22. London: Palgrave.

Ortega, L. (2014). Ways forward for a bi/multilingual turn in SLA. In S. May (Ed.), The multilingual turn: Implications for SLA, TESOL and bilingual education (pp. 32-53). New York: Routledge.

Ortega, L. (2018). "SLA in Uncertain Times: Disciplinary Constraints, Transdisciplinary Hopes”. Working Papers in Educational Linguistics (WPEL) 33 (1): 1-30.

Pachler, N. 2007. "Choices in language education: Principles and policies". Cambridge Journal of Education 37 (1): 1-15.

Pérez-Milans, M. (2013). Urban Schools and English Language Education in Late Modern China: A Critical Sociolinguistic Ethnography. New York: Routledge.

Piller, I. (2016). Linguistic diversity and social justice: An introduction to applied sociolinguistics. New York: Oxford University Press.

Piller, I., and Cho, J. (2013). "Neoliberalism as language policy". Language in Society 42: 23-44.

Preece, S. (2009). Posh Talk: Language and Identity in Higher Education. Palgrave Macmillan. 
Paulston, C. (1978). "Education in a bi/multilingual setting". International Review of Education 24 (3): 309-328.

Petrovic, J. (2005). “The Conservative Restoration and Neoliberal Defenses of Bilingual Education". Language Policy 4: 395-416.

Rampton, B. (2010). "Social class and sociolinguistics". Applied Linguistics Review 1: 1-22.

Ricento, T. (Ed.). (2015). Language Policy and Political Economy: English in a Global Context. Oxford: Oxford University Press.

Ruiz, R. (1984). “Orientations in language planning”. NABE Journal 8 (2): 15-34.

Rydenvald, M. (2015). “Elite Bilingualism? Language Use among Multilingual Teenagers of Swedish Background in European Schools and International Schools in Europe". Journal of Research in International Education 14 (3): 213-227.

Sayers, D., and Lea Láncos, P. (2017). “(Re)defining linguistic diversity: What is being protected in European language policy?” Sky Journal of Linguistics 30: 35-73.

Shankar, S., and Cavanaugh, J. R. (2012). "Language and materiality in global capitalism". Annual Review of Anthropology 41: 355-369.

Selleck, C. (under review). Global ambitions and local identities: New speakers' access to linguistic markets and resources.

Selleck, C. and Barakos, E. (2018). A reflexive approach to researching bilingualism. Paper presented at TLANG Conference Communicating in the Multilingual City, University of Birmingham, 28-29 March 2018. 
Silverstein, M. (1979). Language structure and linguistic ideology. In Clyne, P. R., Hanks, W. F., and Hofbauer, C.L. (eds.), The elements: A parasession on linguistic units and levels, 193-247. Chicago: Chicago Linguistics Society.

Sokolovska, Z. (2016). “Imagining Europe's linguistic diversity in the Council of Europe's

Parliamentary Assembly". Language and Communication (2016): 40-49.

http://dx.doi.org/10.1016/j.langcom.2016.07.004

Sonntag, S. (2003). The Local Politics of Global English: Case Studies in Linguistic Globalization. Lanham, Maryland: Lexington Books.

Sharma, B. (2018). "English and discourses of commodification among tourism workers in the Himalayas". Journal of Sociolinguistics 22 (1): 77-99

Thurlow, C., and Jaworski, A. 2017. "Introducing elite discourse: The rhetorics of status, privilege, and power". Social Semiotics 27/3: 243-254.

Tupas, R. (Ed.) (2015). Unequal Englishes: the politics of Englishes today. New York, NY: Palgrave Macmillan.

Van Zanten, A. (Eds.) (2018). Elites in Education. London: Routledge.

Vogl, U. (2012). Multilingualism in a standard language culture. In M. Hüning, U. Vogl, and O. Moliner (Eds.), Standard languages and multilingualism in European history (pp. 1-42). Amsterdam: John Benjamins.

Waters, J. (2018). "Elites”. British Journal of Sociology of Education 39 (3): 412-419, DOI: 10.1080/01425692.2018.1424104.

Weber, J.J., and Horner, K. (2012). Introducing Multilingualism, a Social Approach. London: Routledge. 